\title{
Review of Common Resources in Ethiopia: Status, Challenges and Management
}

\author{
Galgalo Dika \\ Development Studies (Environment and Development), Addis Ababa University, Ethiopia
}

Copyright $\bigcirc 2018$ by authors, all rights reserved. Authors agree that this article remains permanently open access under the terms of the Creative Commons Attribution License 4.0 International License

\begin{abstract}
This paper presents the conditions, management and challenges of common resources in Ethiopia. Robust reviews of relevant articles, policy papers at the national and international level, proceeding conference paper and seminar works were made. As commons are free to all, its conditions are expressed by saying "resource to all is resource to none" and therefore continued overuse puts common in tragedy. In the previous regime, common property right was characterized by complex and intricate systems in Ethiopia. Under current government land is property of government and Ethiopian people. Common resources in Ethiopia have been managed by different formal and indigenous institutions. In different parts of the country, local community have indigenous institutions in management of grazing land, common forest area and water resources that have stayed with them for many centuries. In addition, formal institutions in management of commons are also playing pivotal roles. The main challenges to common resources are absence of sense of belongingness and indigenous institutions in management of commons per se have been highly marginalized by different external factors. Thus, in order for common resource to be managed sustainably indigenous institutions for management of commons have to be encouraged.
\end{abstract}

Keywords Common Resource, Tragedy of Commons, Common Resource Management, Common Property Right, Ethiopia

\section{Introduction}

To manage natural resources sustainably, ecosystem processes and its interaction between people needs to be understood (Ashenafi \& Williams, n.d.). When it comes to common resources the interaction and usage of resources becomes so severe. This is because, in rural areas communities are highly attached with communal resource use for long period of time, as common property resources affect their livelihoods at large (Dessalegn, 2016). The term "common property resources" in fact relates to those resources for which there is both communal arrangements for the exclusion of non-owners and for the distribution of resources, as well as genuine claims on shared goods for members of known groups (Ashenafi \& Williams, 2005). Management of common call upon the users to co-operate in the inclusion, exclusion and appropriation of the valuable resources that are administered under customary rules (Ashenafi \& Williams, n.d.). These traditional rules are under different institutional arrangements. Sub-Saharan Africa in general and Ethiopia in particular are gifted with plenty of common resources.

Ethiopia for instance, is blessed with plenty of common property resources. The country has very complex and varied structure of indigenous land tenure systems that have evolved through processes (Ashenafi \& Williams, n.d.). Ashenafi \& Williams [1] assess the dynamic of the common property resource management method that functioned in the Guassa area of Menz of Ethiopia and identified Qero system as the main indigenous common property resource management. Unfortunately, Qero system of common resource management come to the end during 1974 socialist revolution in Ethiopia. However as social and economic revolution took place through time Guassa community has redeveloped their indigenous common resource management system. On the other hand, the study by Dika [20] on the role of indigenous knowledge in rangeland management in Borana pastoral community of southern Oromia reveals, there is high degradation of rangeland resources. In order to overcome this degradation, Borana pastoralists have developed highly efficient range management strategies to deal with the high-risk environments of arid lands.

Common pool resources, challenges and managements are varied in the country from area to area. Taking a look at forest resources, in different area people traditionally manage forest resource as forests are the place of rituals, religion and some cultural activities. For instance, Eshetu [37] confirmed that there were different intentions and motives for management of forest resources. Participatory forest management (PFM) is one of them. The PFM was introduced during the early 1990 s by some non-governmental organization and still exists in the country (Gobeze, Bekele, Lemenih, \& Kassa, 2009). It was meant to prevent the insistent problems of deforestation and to bring improved social and economic outcomes (Alemayehu, Nathalie, \& Bas, 2015). In addition, water is common resources of the county. Ethiopia has a plentiful gift of water, but this water is distributed unevenly in space 
and time (Beatrice, et al., 2015). There are different indigenous and formal water management techniques in different parts of the country. For instance, according to Dika [20] in Borana lowland of southern Ethiopia there are different indigenous institutions responsible for management of water points both for livestock and domestic consumptions.

\section{Theoretical and Conceptual Framework}

\subsection{Garrett Hardin's Tragedy of Commons}

Mathematician William Forster Lloyd have first advanced concept of the tragedy of the commons in 1833 (Stebek, 2011). However, it becomes highly influential in scientific debates for many years since Garrett Hardin's publication of thesis on tragedy of commons in 1968. Hardin's simple but influential tale of herdsmen sharing a common pasture has sparked debate in a wide range of disciplines and given birth to a far-reaching research work undertaken by many scholars (Latta, n.d.). The tragedy of the commons develops because pasture is open to all and each herdsman keeps as many livestock as possible on common. This kind of arrangement may work for centuries because number of both livestock and human are well below carrying capacity of land. Finally, however, as number of human population and livestock start growing alarmingly, overexploitation and degradation of commons occur as population exceeds carrying capacity of land. At this point, the innate logic of the commons cruelly generates tragedy which may put both livestock and human population under risk (Hardin, 1968).

Tragedy of commons was ecologists' interpretation of problem of human population growth. It has become widely accepted as the theoretical framework for interpretation of dynamic causes of resource over-exploitation. According to Hardin, herdsman sharing common pasture may overstock their herds and consequently destructions of common occurs. The concept of degradation of pasture has been applied widely in degradation of several common goods like forests, water resources, atmosphere and others (Latta, n.d.).

Some authors indicated that tragedy of commons is not free of criticism. Confusion between common property management regimes (CPMR) and open access was intensified by the 'tragedy of the commons' article of Hardin [9]. So, Hardin failed to distinguish between CPMR and open access. This theory has become so influential in tropics and other parts of the world as individualistic nature of resource users leads to over-exploitation of resource (Richards, 1997). But common property resources are also open for those who had them in common. In this regards, open access and common property have no significant difference, except the latter is owned by some group while the former is free for all.

\subsection{Conceptual Framework}

The main objective of this review paper is to have better understanding of the status, challenges and management of common resources in Ethiopia. In this review the major topics to be enclosed are status, management and challenges of common resources in Ethiopia. Particularly this paper focused on pasture, common forest and water resource management. Indigenous common resource management techniques from selected part of country are covered. Particularity in rural area there are different common resource management systems. Nonetheless, indigenous knowledge of community in natural resource management are facing problems from time to time which leads to declining of different institutions of resource management. The conceptual framework is presented in figure 1 below.

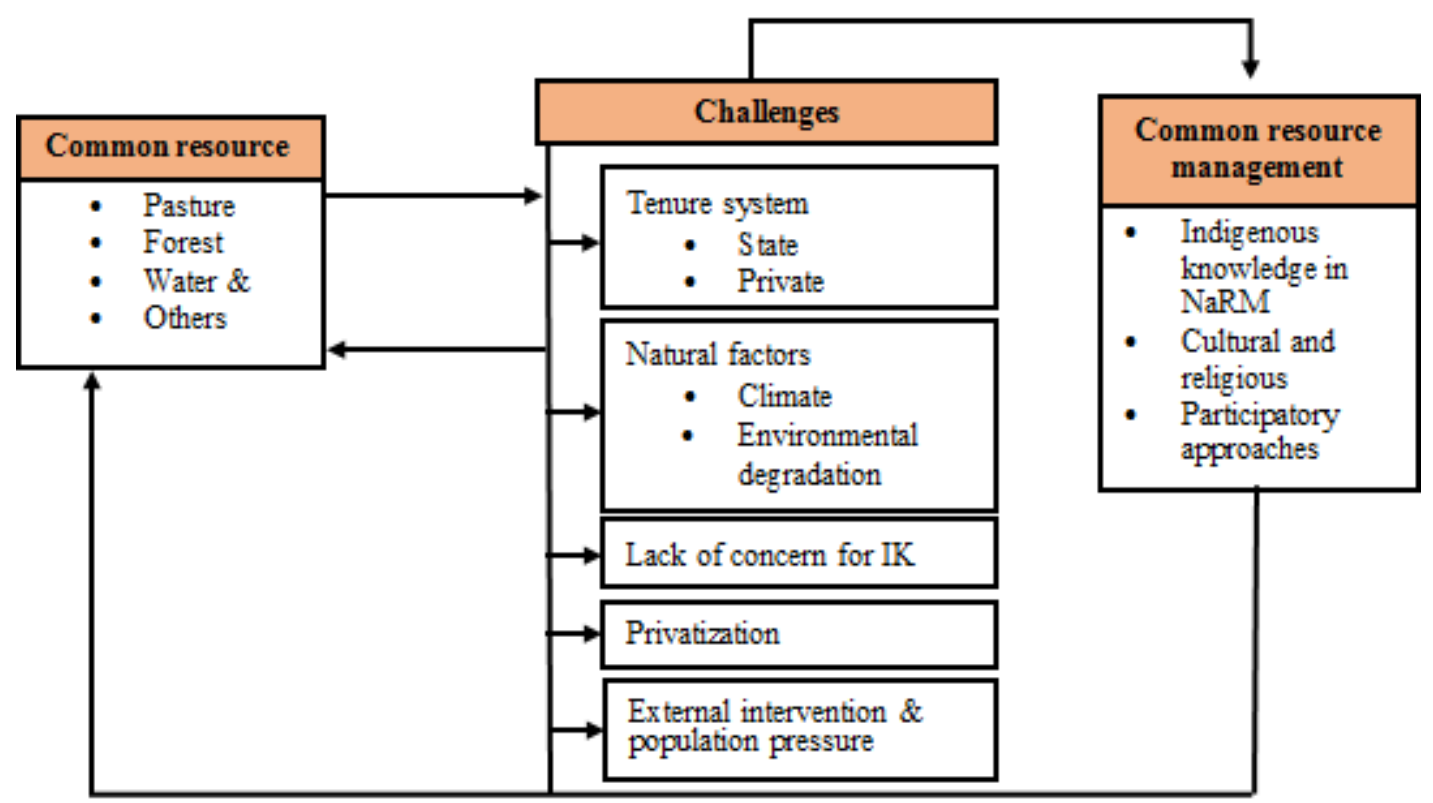

Figure 1. Conceptual framework 


\section{Results and Discussion}

\subsection{Definitions and Concepts of Commons}

For past two-decades the concepts of common property have been highly misinterpreted. It is organized ownership arrangements within which management rules are developed, group size is known and enforced, incentives exist for co-owners to follow the accepted institutional arrangements, and sanctions work to insure compliance but it is not free to all as it has been described (World Bank, 1989). It can be further defined as follows.

Common resources are those resources which can be used commonly by different users because of difficulties in claiming or enforcing exclusive rights, or because they are so scarce or indeterminate that it is not worth doing so. As oppose to open access resources, common property resources are managed by institutions who claim ownership and management rights over the common resources on behalf of a known group. These rights include the right to deny access to those who do not belong to the community, and to regulate the misuse of the resource by members. Common property systems generally include all community based or customary resource management systems (Hesse \& Trench, 2000).

For the past 20 years' literature on common resources can be summarized by the sentence "everybody's property is nobody's property." when a given natural resource is commonly accessible to more than one user, the result is said to be a free-for-all, with users competing with for a greater stake of the resource to the detriment of themselves, the resource, and society at large. The concepts of common resource exploitation have been applied many resources including fisheries, grazing lands, forestry, groundwater, oil, air, campgrounds, and even highways and the radio spectrum. Common property condition is widely blamed for a host of social problems including resource depletion, pollution, dissipation of economic surplus, poverty among resource users, backwardness in technology, and misallocation of labor and capital (Wantrup \& Bishop, 1975). Therefore, the central argument of this paper is that common resources are under threat from different physical, environment and social interventions. Thus, for sustainable and effective management of commons boundless emphasis has to be given to customary institutions and indigenous knowledge of resource users at large.

\subsection{Common Resources in Ethiopia}

Ethiopia is a country of diverse ethnic, religious and cultural group. The country is gifted with plenty of common resources. In different parts of the country there are different formal and informal institutions in management of natural resources. Under the following sections, common property rights, management of common resources and challenges of common resource management in Ethiopia were discussed. Under different government regimes different complex and interactive property right system had developed. Herein under, formal and informal institutions on management of commons grazing land, forest area and water resources were discussed. These resources are linked with the livelihood of resource dependent rural community. Rural community has developed the efficient and sustainable knowledge of resource management. Nonetheless, this indigenous knowledge of local community has been considered archaic and traditional and was challenged by different external interventions.

\subsection{Common Property Right in Ethiopia}

Land is the primary means for livelihood generations, main vehicle to invest, accumulate wealth and transfer it between generations for the most of the poor in developing countries (Zerga, 2016). The same thing holds true in context of Ethiopia. Agrarian, pastoralist, agro-pastoralist and even dwellers of towns depends on land one or the other way. Agriculture is backbone of economy taking lions share in GDP of the country. The livelihoods of more than half of the country as well depend on this sector. People of Ethiopia majority of which are rural practices agriculture, pastoralism and agro-pastoralist activity. Therefore, there is no doubts that the life of all Ethiopian depends on land resource and its sustainable management and uses. In Ethiopia land has been subjected to different ownership and use rights throughout history.

Land had been managed by the elite (kings and their trusted group) in Ethiopia. Private ownership of land had not ever been known excluding for some historical events. The land tenure system in pre-1975 Ethiopia was one of the most complex and enmeshed systems. Landlord tenant and rist is the main tenure institutions. The most common types of land related institutions in pre-1975 Ethiopia were rist, gult, maderia (Yemengist) land, and semon (Church) land (Zerga, 2016). In 1975 under socialist Derg regime, the public ownership of rural land proclamation nationalized all rural land and set out to redistribute it to its tillers and to organize farmers in cooperatives, thereby abolishing exploitative landlord-tenant relations so pertinent under the imperial regime (Crewett, Bogale, \& Korf, 2008). Therefore, to have access to land one has to be member of peasant association and there was periodic redistribution of land among households based on family size and land quality (Zerga, 2016).

Under current federal democratic republic of Ethiopia (FDRE), the right to ownership of rural and urban land, as well as natural resources is exclusively vested in the State and in the peoples of Ethiopia and shall not be subject to sale or to other means of exchange (Article 40/3 of constitutions of FDRE). One of the important issues that can be raised in relation to public property of rural land and natural resources is whether it has the impact of open 
access to a substantial part of these resources. Addressing this issue is essential because publicly owned resources can be vulnerable to de facto open access (Stebek, 2011). The Ethiopian government has begun implementation of 'land certification program' hoping that it improves tenure security of peasants (Zerga, 2016). The four major regions of country, Oromia, Amhara, Tigray and SNNP have been conducting this.

\subsection{Management of Commons Resources in Ethiopia}

The critical questions in the decentralization and reformation of tenure in sub-Saharan states are the way commons are defined and managed. Governments may enact new legislation to transfer the responsibility for managing natural resources to local communities, but despite rising awareness of the vital role of the commons in local livelihood systems, there is still some confrontation to transferring full management of their use to the communities that depend upon them. Some policy makers are uncertain as to whether common resources can be properly managed by community-based organizations, and it is still believed that privatization or state control are the only means of preventing the degradation of resources that are customarily held in common. The alternatives, which range from full local control to joint management by the community and the state, are relatively new and untested. Therefore, for management of common resources there are no simple solutions or blanket remedies that can serve as models because these resources are diverse in nature and location (Hesse \& Trench, 2000). However, customary institutional structure of the communities has maintained the resources in sustainable way for long period of time (Ogato, 2006).

\subsubsection{Indigenous Common Grazing Land Management}

Local community in different parts of the country has their own means of common resource management. For instance, serege-commons is found in Muhur area of Gurage zone within the southern nations and nationalities in Ethiopia. It consists of grazing areas and woodland. They are used for grazing, keeping, and herding livestock. The Muhur are sedentary farmers whose system of crop cultivation relies on extensive use of manure for keeping livestock and securing access to manure essential for crop production. This common are managed through local hierarchical structures, including village, parish, and supra-parish levels. The uses and management of resources are by customary regulations, norms, and practices. Attempts to circumvent the local practices using undercover strategies may involve encroaching on parts of the commons and illicit tree cutting. Such misbehaviors will first be dealt with by the village-based local structure. It is led by a dagna (customary judge) noted for customary dispute-settlement skills. The dagna is aided by a council of elders with customary mediation skills (Dessalegn, 2016).
Uses of resources are allowable or controlled depending on users' customary rights of entitlement and accountability based on their social membership and spatial placement within the social-ecological unit of the commons.

On the other hand, study by Ashenafi and Williams [1] in the Amhara Regional State of North Shoa Zone, in the Gera-Keya Woreda (District) popularly known as Menz reveals, in the Guassa area common property resource management worked under an indigenous resource management institution known us the Qero system. This system based on the existing Atsme Irist indigenous land tenure system. The rules of exclusion governing the use of the Guassa area resource were aspects of the Atsme Irist land tenure system that conferred usufruct right on the members of a group tracing their lineage back to their pioneer fathers. Furthermore, the user community was organized at parish level, an arrangement that gave the Guassa area the status of consecrated land, under protective patronage of the Christian church in Ethiopia. However, Qero system is highly weakened through time. Currently, according to Sifraayishu [40] people are determined to protect commons for the sustainable use of Guassa grass.

Regarding other parts of the country, for instance, Afar traditional institutions allow two types of resource users. The first users include clan members who use the rangeland permanently. They are primary right-holders (waamo) who have the right to use the resource, exclude others and to transfer to their heirs. The second type of resource users are groups of neighboring pastoralists whose demands for pastoral resources go beyond their own endowments, particularly during drought years. They are secondary right-holders and have frequent access to clan resources that is generally recognized and accepted by clan members and traditional leaders. Nevertheless, there are certain obligations that secondary right-holders should obey in order to obtain access to the resources. They have to first negotiate with waamo right-holders, the success of which depends upon the relationship between the two groups and resource conditions. Secondary right-holders are required to honor the customary rules of the host group if they get access to the resources. For instance, they should protect resource as their own by refraining from actions such as cutting trees, allowing other herders to use the resources, and rushing their livestock into reserved areas (Hundie \& Padmanabhan, 2008).

Furthermore, the Afar utilized mobility between different grazing landscapes distributed in space and time. The grazing rangelands are geographically separated between the uplands (ale), lowlands (bahari), narrow (duulul balaa) and wide valleys (daaba). The floodplain with their key grazing resources (kaalo) and the valleys used for dry season grazing reserves, while the uplands were used for wet season grazing. The plains were grazed soon after the rains when the soils dried and the grass flowered. The system of grazing movements and the selections of different grazing landscapes varied with the 
types of livestock species. At the broader scale, the Afar grazing lands are categorized into communal grazing, where all the neighboring clans shared grazing and water during the wet season. Each clan however has territories (faage) to which their livestock returned during the dry season. The clan territories are preserved while the communal grazing areas were exploited (Oba, 2009).

Whereas, in Borana pastoralist area common grazing lands are managed by division of herds, reserved grazing area, animal mobility, migration of ollas, demarcation of settlement and grazing area and so forth (Angassa \& Beyene, 2003; Dika, 2016). In addition, Rangelands are managed by different costmary institutions (Dika, 2016; Homann, 2005). Customarily, management of land (pasture) is not a clan responsibility among the Borana, but the responsibility of 'territorial units' called dheedhas (Nassef \& Belayhun, 2012). Jaarsa Dheeda is the responsible person for managing the uses and access of grazing land. In Borana the access, uses and management of grazing land is responsibility of Borana. Being Borana is enough to have access to the resource within Borana area. Figure 2 below presents hierarchy of resource management in Borana.
Ethiopia is gifted with diverse vegetation resources ranging from high forests, woodlands, bushlands, plantations, and trees outside forests. Each of these vegetation resources significantly contributes to the production, protection and conservation functions, and play significant role in the national and local economy (Gobeze, Bekele, Lemenih, \& Kassa, 2009). However, Natural resources degradation, a major form of which is deforestation and de-vegetation, has become a serious problem in Ethiopia (Ango \& Bewket, 2007). Rapid population growth, which urges an increase in the demand for crop and grazing land, wood for fuel and construction are the major causes of deforestations. Lack of feasible land use policy and corresponding law further aggravated the rate of deforestation. New settlements in forests are increasing from time to time and hence resulted in the conversion of forested land into agricultural and other land use systems. Currently, the few remaining high forests are endangered by pressure from investors who are changing the moist evergreen montane forests into other land use systems such as coffee and tea plantations (Bekele, 2001). Nonetheless, government, local community and some NGOs have been trying their best to reverse the course.

\subsubsection{Common Forests Area Management}

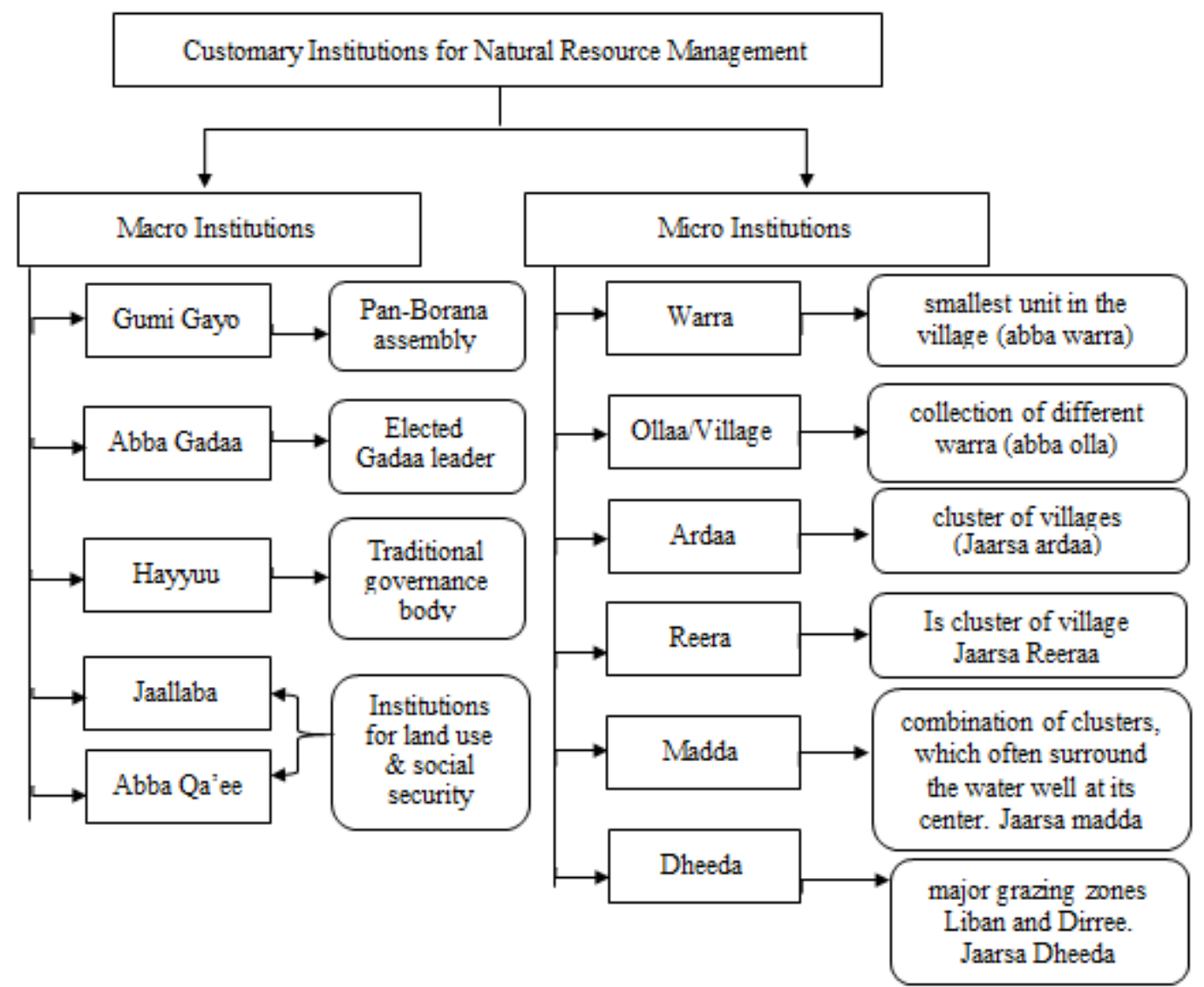

Source: Own design after Dika [20]; Homann [21]

Figure 2. Customary Institution of Borana in Natural Resources Management 
Participatory forest management is one of such efforts. It was introduced in Ethiopia around the mid-1990s as a new system of forest governance. The objective of PFM was to stop the persistent problems of deforestation and deliver better social and economic outcomes compared with the former centralized command-and-control resource management approach. PFM is recognized as a co-governance institutional arrangement where forest management responsibilities and use rights are legally shared between a government agency and a community-based organization (CBO), such as forest user groups or forest cooperatives (Alemayehu, Nathalie, \& Bas, 2015). It was introduced as a complementary mechanism which safeguards forests, while respecting traditional users and including them in the process (FAO subregional Office for Eastern Africa, 2011).

PFM have been subjected to criticism from growing number of scholars. Some claim major change in forest management has taken place consequent to PFM on the management of physical resources, institutional arrangements and livelihoods of resource-dependent communities. Other for instance, Alemayehu et al. [5] claim that, despite the establishment of such a new institutional arrangement local forest management practices have hardly been shaped by the objectives and rules of the PFM approach. On the other hand, the study by Gobeze et al. [4] indicated that, the potential of PFM as a vehicle to promote sustainable forest management provided that the capacity of institutions at local level is built and the government is committed to support them. In addition to PFM different local institutions have been playing critical role in forest management.

The study by Assefa [27] revealed the existence of various formal and customary institutions that influence forest management and use in Yayu Forest. The formal institutions contributed to forest resource management in carrying out collective choice level activities such as alienation and exclusion and determine operational level activities. On the other hand, informal institutions such as council of elders, religious institutions, Jiga, Dabo and Iddir, were involved in operational level activities such as time of forest resource harvesting, time of marketing, time of coffee planting, and clearing undergrowths. Additionally, informal institutions are also used as a platform by government to initiate formal discussion to raise awareness about forest resources use, management and conservation. Similar to Yayu community, Bilo-Nopha community have Iddir, council of elders, and Jiga as customary institutions for forest management (Dibaba, 2016).

These informal institutions have various role in forest management. Jiga is a voluntary self-help customary institution, which provides support for a person or a family faced with severe problems. Now Jiga is mainly used as a forum for formal discussions between the community and the government-initiated institutions about forest resources use, management and conservation activities. The role of
Iddir in resource conservation activities is mainly in disseminating information related to any development issue including forest resource use and management to the local community by government-initiated institutions on every occasion. Dabo is a voluntary self-help organization in which members of the community participates in various duties mainly agricultural. It is organized to perform various activities which, includes farming, sowing, winnowing, house construction, clearing forest undergrowth for coffee production, coffee transporting, and others (Assefa, 2010).

In jimma zone, local community conserve forest tree species traditionally either for religious practices or for benefits they drive from the forest as in the case of coffee shade tree (Hundera, 2007). Other than the benefits trees bring to them in many parts of the country religious values play critical roles in forest conservation. For instance, according to the study in Church forest of North Shewa zone of Amhara region, forest is protected by the commitment of the church based on strong theological thoughts and biblical basis. Local community respects and protects church forests and considers the church as a central institution and platform. An example of such forest is Debre Menkirat Mitak Amanuel Monastery in Between Ankober and Basona Werana. The conserved monastery forests nearby church can be found in different parts of the country. However, the community is not strongly committed to adopt forest management culture of the church due to the fact that (1) church leaders do not teach about forests, (2) limited knowledge of the community about the benefits of forests (Tilahun, Terefe, \& Soromessa, 2015). There is other institutional arrangement in different parts of the country.

Komba village in Koma forest of Kaffa Zone in southwestern Ethiopia, have two institutional arrangements namely (a) the institutional arrangements for collective coffee forest management (including harvest of forest coffee berries), which have taken the organizational form of neighborhood working groups; and (b) the legislative and juridical structures that provide the operational set of institutions determining land and forest resource property rights. For collective labour, two types of working groups are relevant in Komba village: daddo and dabbo. Both provide short term work teams beyond kinship ties on the basis of equal labour exchange in times of high labour demand. A daddo working group consists of about three to five people working together for half a day. Dabbo is much bigger than daddo in terms of workforce involved, expenditure of time and action radius (Stellmacher, 2013). Even iddir as in case of Yayu forest, have the role in forest management through participation of members in forest management and punishment of member who stand against regulation of forest management.

\subsubsection{Water Resources Management}

Water has a strong tie to the physical and spiritual well-being of humankind. Regardless of the differences in 
religion, culture, and social norms, every person depends on water (Behailu, Pietilä, \& Katko, 2016). Planet earth have got a plenty of water. Majority of this water are found in ocean, stream, lake, icecaps and other sources. In east Africa there are abundant water resource many of which particularly rivers which cross national and international boundary. As part of focus of this paper, Ethiopia is said to be water tower of horn of Africa as it has a generous endowment of water, but this water is distributed unevenly in space and time. Unmitigated hydrological variability, compounded by climate change, has been estimated to cost the country roughly one third of its growth potential (Beatrice, et al., 2015). These unevenness, scarcity and problems with water resources have been managed with different techniques ranging from technical to traditional. Herein under indigenous water management system of Borana, Konso and Somali are discussed.

Due to the scarcity of surface water, traditional wells are the most important source of water for pastoral communities in the Borana Zone of Southern Ethiopia. These wells, known in the local language as eela, are a significant part of social, economic and even religious aspects of pastoral life (The Global Water Initiative, n.d.). In order to manage this resource Borana pastoralist have developed excellent indigenous knowledge system. The traditional water systems are related to water sources which are accessible easily, including springs, rainwater, shallow wells, and exceptionally deep wells in Borana (Behailu, Pietilä, \& Katko, 2016). Deep wells are commonly known as tulaa in Borana. The ancient tulaa well system, the main permanent water source, has been in operation for more than five centuries and it closely links human activity and the environment. The welfare of the tulaa well system and the performance of the Borana pastoral system are directly related to ancient tulaa wells that has had a critical function in the sustainable management of savanna grazing lands in southern Ethiopia. The wells play a pivotal role in Borana pastoral production, cultural identity, and the institutional organization of water management (Tiki, Oba, \& Tvedt, 2011). In addition, Adaadii (shallow) wells are other important water points used and managed by Borana pastoralists (Doyo, 2011).

The traditional administration system in Borana is known as Gadaa system which is traditional socio-political administration. Gadaa is macro level management which have under it different institutions for resource management. In Borana area there is customary institutions for resource management. Water and pasture are on the top of the agendas of resource management as pastoralist depends on pasture and water for cultural and domestic consumptions of both human and livestock. In Borana, well is owned by a distinct clan and managed by the father of the eela (Konfi). Even though, the Konfi is the head in managing eelas, it is the property of all Borana community. Generally, in well management there are well council, Abba herega (officer) and Abba Guyyaa (Daily turn holders) (Behailu, Pietilä, \& Katko, 2016). There are many categories of well maintenance: (a) daily maintenance of removing dung, (b) seasonal maintenance to clean a sediment deposit after flood season, and (c) major well rehabilitation and extension of the depth of well following the depletion of a groundwater table (Coppock, 1994).

Like that of Borana community Konso people have their own means of managing pond water. Konso are one of indigenous people in Ethiopia known by their landscape (Konso terrace) which was already registered by UNESCO as cultural landscape. They believe that each water source has a spirit, which usually communicates with the landowner while he is asleep. In Konso nobody is assigned for control at water sources, and rules are respected in Konso even in the absence of caretakers (Behailu, Pietilä, \& Katko, 2016).

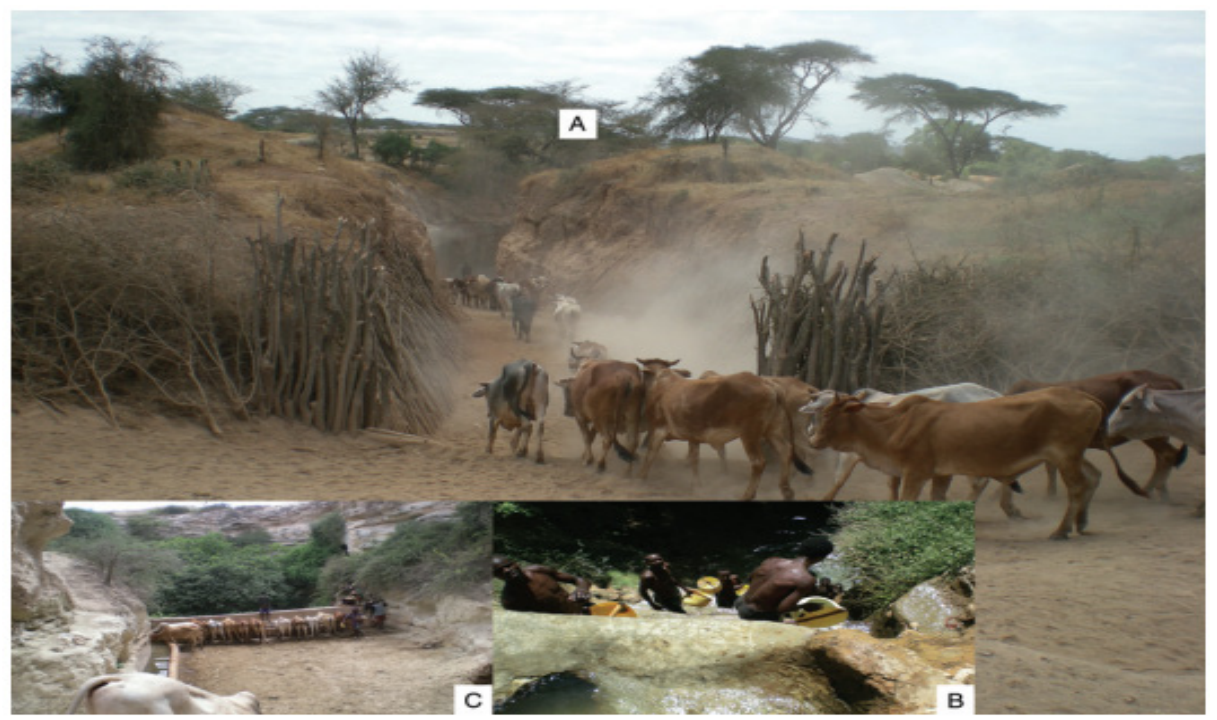

Sources: Tiki, Oba, \& Tvedt [33]

Figure 1. (A) Cattle walking into well through well ramp. (B) Insert showing men lifting water from $15 \mathrm{~m}$ depth of the well to the trough. (C) cattle drinking at the trough 
Unlike the Borana, territories in Somali are associated with particular clans and sub-clans, with fluid boundaries between them. The common water sources with different territories are rivers, ponds, shallow and deep wells and birkado. Devereux (2006) in (Nassef \& Belayhun, 2012) indicated that nowadays, water use systems in Somali differ according to location within the region and are differentiated by dry season water resources and how they are used. Birkado is the only source of water in the dry season of somali. Water access is usually against payment as birkado are generally privately owned. The private ownership of birkado means potential exclusion from water access for those with no means to pay (or for other reasons), which in turn means exclusion from surrounding grazing (for those birkado which are also used for watering livestock), forcing herders to seek out other birkado with more agreeable owners or provoking conflict over access. Birkado are usually owned by wealthier individuals (or sometimes groups) who have the means to pay for the considerable construction costs. Those who cannot afford to construct their own birkado have to pay for access, where the price of water is negotiated on an individual basis and depends on the season, at its highest in the dry season (Nassef \& Belayhun, 2012).

Where there is adequate groundwater, hand dug wells are common and are usually belongs to clans but are sometimes owned individually. When water is abundant, clan possessed wells are open access to other clans living in the area and for those migrating in search of water. Water is free, and water sale is not a usual practice. However, access to water follows an established hierarchy, which is strictly enforced especially in times of scarcity. The person who constructed the well and his family are first in line to the water, followed by clan members, and non-clan members last. Deep wells, which require considerable labour for excavation and water extraction, follow a similar management system as for the Borana (Nassef \& Belayhun, 2012).

\subsection{Challenges of Common Resources}

Common resources in Ethiopia are facing a number of challenges. As it has been stated by Garett Hardin's and other writers on commons, "everybody's property is nobody's property". The concepts of tragedy of commons together with increased number of livestock and human population have exacerbated overexploitation of common resources in country. In addition, natural phenomenon has detrimental impacts on depletion of resource base. For instance, impacts of climate variability and change like recurrent drought, erratic rainfall, temperature extreme, EINino and others have been worsening the condition. Therefore, both natural and anthropogenic factors are leading to depletion of common resources. Other than this, indigenous resource management of community is also facing serious challenges from external factors.
African pastoral systems in general and Ethiopian pastoral system in particular are facing external factors. For instance, in Borana and other pastoral areas of county indigenous knowledge in rangeland management have been disturbed. The main reason for this are a well-intended but poorly designed pastoral development, the establishment of private commercial ranches, marginalization of role of indigenous knowledge and others (Homann, 2005; Dika, 2016).

Common resources are facing other problems like central state intervention, markets or privatization of property rights over resources as matter of course (Agrawal, 2001). Central state intervention in a sense mean that interventions and marginalization of decision made by local institutions and ignorance of customary rules of resource management. On the other hand, many areas of common resources in the country have been privatized. Agrawal [36] further confirmed that, common pool resources suffer from substantive problem. These are the cost facing local institutions of commons. Local resource management can result in efficient, equitable and sustainable conservation of common resources. However, neglecting of these local institutions by external social, physical and institutional environment has been worsening the conditions.

Like that of Borana pastoralist, in Afar region of Ethiopia traditional land use arrangements are being transformed. External interventions are the main drive for this transformation. The intervention of the state in Afar was very limited prior to the 1960s. Farming was limited to the lower Awash flood fed plains, where some pastoralists in the Asahimarra section of Afar had been practicing mixed crop livestock farming for generations. Currently, state is the major source of changes in property right in the middle Awash valley of Afar region (Hundie \& Padmanabhan, 2008). Other challenge is the way community manages resources. In afar access to use and management of resources is by clan and common grazing areas are openly available for all. In this regard, the clan territories are preserved while the communal grazing areas were exploited (Oba, 2009).

Ethiopia's montane rainforests have witnessed high rates of depletion and deforestation in the last decades. The main reasons are expansion and intensification of smallholder agriculture and forestry. Forest governance in Ethiopia is characterized by the complex interaction of factors such as nationalization of land, weak state structures, the persistence of traditional local institutions, and sociocultural heterogeneity promoted by state-enforced resettlement (Stellmacher, 2013). Traditional administrative setups for managing forest resource have been eroded by modern administrative setups in Jimma zone and other forest areas of the country (Hundera, 2007). In addition to this, clearing of forest for expansion of agriculture and growing number of investors on coffee production in rainforest area of the country are currently a 
big problem. Furthermore, lack of commitment and sufficient support from government, mainstreaming of PFM as an alternative approach to managing forests in the country is weak and there is no regular forest monitoring (Gobeze, Bekele, Lemenih, \& Kassa, 2009).

\section{Conclusions}

The Ethiopian people had been struggling for centuries with the inequitable land holdings of the country and in the past the property right of land is complex where state fully controlled both urban and rural land. Even under current government land is property of state and people of Ethiopia, so that it cannot be sold and changed in any case. But the argument here is that, publicly held land may be subjected to open access and in any case, it might be difficult to build sense of belongingness in a society. The property right regimes in different regime of government have weakened the customary institutions of resource use and management in different parts of the country. The state ownership and private ownership of land is the most debatable issues. Proponents of private ownership say farmers can invest whatever means of land management on land he/she own.

Ethiopian people from different parts of country have developed the most efficient and sustainable resource management system. Both formal and informal institutions have been playing critical role in management of commons. For instance, Borana, Afar and Somali pastoralist have developed the exceptional systems for management of grazing land and water resources. In addition, there are also different formal and informal institutions in management of common forest area. However, this excellent system of resource management has been weakened though time with influence of different external factors like state intervention, privatizations and marginalization of indigenous knowledge of community. In general, customary tenure systems with their communal forms of ownership and management were considered to be archaic, locking people into a 'tragedy of the commons' scenario. Nevertheless, this days government together with different national and international organization has been giving due consideration to indigenous resource management.

\section{Conflict of Interests}

The author declares no conflicts of interest.

\section{REFERENCES}

[1] Z. T. Ashenafi and N. L. Williams. The Resilient Nature of Common Property Resource Management Systems: a case study from the Guassa area of Menz, Ethiopia. Addis Ababa, n.d..
[2] M. Dessalegn. Threatened common property resource system and factors for resilience: lessons drawn from serege-commons in Muhur, Ethiopia. Ecology and Society, pp. 1-11, 2016.

[3] Z. T. Ashenafi and N. L. Williams. Indigenous Common Property Resource Management in the Central Highlands of Ethiopia. Human Ecology, vol. Vol. 33, no. No. 4, 2005.

[4] G. B. L. and K. Participatory forest management and its impacts on livelihoods and forest status: the case of Bonga forest. International Forestry Review, vol. 11, no. 3, pp. 346-358, 2009.

[5] N. A. Alemayehu, V. Nathalie and A. Bas. Performance of participatory forest management in Ethiopia: institutional arrangement versus local practices. critical policy studies, pp. $1-20,2015$.

[6] M. Beatrice, C. Roger, . T. osephine, P. Helen, A. Tena, K. Seifu , A. Tesfay and G. Assefa. Building adaptive water resources management in Ethiopia. Overseas Development Institute, London SE1 8NJ, 2015.

[7] E. N. Stebek. Conceptual Foundations of Property Rights: Rethinking De Facto Rural Open Access to Common-Pool Resources in Ethiopia. Mizan Law Review, vol. Vol.5, pp. $1-40,2011$.

[8] P. A. Latta. THE TRAGEDY OF THE COMMONS" BY GARRETT HARDIN, 1968. Encyclopedia of Life Support Systems (EOLSS), n.d..

[9] G. Hardin. The Tragedy of the Commons. Science, vol. vol. 162, pp. pp. 1243-1248, 1968.

[10] M. Richards. TRAGEDY OF THE COMMONS FOR COMMUNITY-BASED FOREST MANAGEMENT IN LATIN AMERICA?. Natural Resource Perspectives, pp. $1-12,1997$.

[11] World Bank. The Management of Common Property Natural Resources Some Conceptual and Operational Fallacies. Washington, D.C.: Libraryof Congress Cataloging-in-Publication Data, 1989.

[12] C. Hesse and P. Trench. Who's Managing the Commons? Inclusive management for a sustainable future. Nottingham: Russell Press, 2000.

[13] C. S. V. Wantrup and R. C. Bishop. COMMON PROPERTY" AS A CONCEPT" IN NATURAL RESOURCES POLICY. Natural Resources Journal, vol. 15, pp. 713-727, 1975.

[14] B. Zerga. Land Resource, Uses, and Ownership in Ethiopia: Past, Present and Future. International Journal of Scientific Research Engineering Technology, vol. Vol.2, no. 1, pp. 17-24, 2016.

[15] W. Crewett, A. Bogale and B. Korf. Land Tenure in Ethiopia: Continuity and Change, Shifting Rulers, and the Quest for State Control. CAPRi Working Paper 91. International Food Policy Research Institute, 2008.

[16] A. Ogato. Indigenous common Grazing Land Management in Chencha Wereda, South Ethiopia. Addis Ababa University, Addis Ababa, 2006.

[17] B. Hundie and M. Padmanabhan. The transformation of the Afar commons in ethiopia: stata coercion, diversitication, 
and property rights change among pastoralists. Collective Action and Property Rights (CAPRi) Working Paper No. 87, pp. 1-37, 2008.

[18] G. Oba. Harnessing Pastoralists' Indigenous Range Management Knowledge for Drought -Resilient Livelihood Systems in the Horn of Africa. World Institute for sustainable pastoralism, 2009.

[19] A. Angassa and F. Beyene. Current range condition in southern Ethiopia in relation to traditional management strategies: The perceptions of Borana pastoralists. Tropical Grasslands, vol. Vol. 37, pp. pp. 53-59, 2003.

[20] G. G. Dika. The Role of Indigenous Knowledge in Rangeland Management in Yabello Woreda, Southern Oromia, Ethiopia. Arts and Social Sciences Journal, vol. Vol. 7, no. 2, pp. pp. 1-8, 2016

[21] S. Homann. Indigenous knowledge of Borana pastoralists in natural resource management: a case study from southern Ethiopia. Göttingen : Cuvillier Verlag, 2005.

[22] M. Nassef and M. Belayhun. Water and Development in Ethiopias Pastoral Areas: Synthesis of Existing Knowledge and Experience. Save the children USA and oveseas development institute, 2012.

[23] T. G. Ango and W. Bewket. Challenges and Prospects for Sustainable Forest Management in Wondo Genet Area, Southern Ethiopia. Ethiopian Journal of Development Research, vol. Vol. 29, pp. pp. 27-64, 2007.

[24] M. Bekele. Forestry Outlook Studies in Africa (FOSA): Ethiopia. 2001.

[25] FAO subregional Office for Eastern Africa. Participatory Forest Management in Ethiopia, Practices and Experiences. FAO, Addis Ababa, 2011.

[26] B. Dibaba. Incentives and Challenges for Local Institutions in Coffee Forest Management: The Case of Bilo-Nopha Woreda, Illu Abba Bora Zone. Addis Ababa University, Addis Ababa, 2016.

[27] A. D. Assefa. Local Institutions and their Influence on Forest resource Management in Southwest Ethiopia: The Case of Yayu Forest. Addis Ababa University, Addis Ababa, 2010.

[28] K. Hundera. Traditional forest management practices in Jimma zone, south west Ethiopia. Ethiopia journal of Education and science, vol. Vol.2, pp. 1-9, 2007.

[29] A. Tilahun, H. Terefe and T. Soromessa. The Contribution of
Ethiopian Orthodox Tewahido Church in Forest Management and Its Best Practices to be Scaled up in North Shewa Zone of Amhara Region, Ethiopia. Agriculture, Forestry and Fisheries, vol. Vol.4, no. 3, pp. 123-137, 2015.

[30] T. Stellmacher. Local forest governance in Ethiopia: Between legal pluralism and livelihood realities. Bonn, 2013.

[31] B. M. Behailu, P. E. Pietilä and T. S. Katko. Indigenous Practices of Water Management for Sustainable Services: Case of Borana and Konso, Ethiopia. Special Issue-Traditional Wisdom, pp. 1-11, 2016.

[32] The Global Water Initiative. Traditional Wells and Water Management Systems: GWI Experience with Pastoralists in Southern Ethiopia. n.d..

[33] W. Tiki, G. Oba and T. Tvedt. Human stewardship or ruining cultural landscapes of the ancient Tula wells, southern Ethiopia. The Geographical Journal, vol. Vol. 177, pp. 63-78, 2011.

[34] J. Doyo. Indigenous Practices of Rangeland Management: Constraints And Prospects in Borana Pastoralists of Southern Ethiopia, Oromia Regional State. Addis Ababa University, Addis Ababa, 2011.

[35] D. L. Coppock. The Borana Plateau of Southern Ethiopia: Synthesis of pastoral research, development and change. 1980-91, Addis Ababa: ILCA (International Livestock Centre for Africa), 1994

[36] A. Agrawal. Common Property Institutions and Sustainable Governance of Resources. World Development, vol. Vol.29, pp. pp.1649-1672, 2001.

[37] A. A. Eshetu. Forest resource management systems in Ethiopia: Historical perspective: Review. nternational Journal of Biodiversity and Conservation, vol. vol 6, no. 2, pp. 121-131, 2014.

[38] J. Briggs. The use of indigenous knowledge in development: problems and challenges. Progress in Development Studies, vol. Vol.5, no. 2, pp. 1-29, 2005.

[39] A. B. Dixon and A. P. Wood. 8 Local institutions for wetland management in Ethiopia: Sustainability and state intervention. 2007.

[40] G. a. Sifraayishu. Opportunities and Challenges of Community Based Natural Resource Management in Menz-Guassa Community Conservation area, Ethiopia. Addis Ababa University, Addis Ababa, 2014. 